\title{
Practices of Micro Enterprises in Nepal
}

\author{
Bir Bahadur Karki, PhD
}

\begin{abstract}
Entrepreneurship is perceived as an effective way to escape from poverty and paternalism. In developing countries, the informal sector is an important source of employment. Micro-enterprise is a tiny industry usually of 1-10 people that is profitoriented and may be owned by a man or a woman. Micro Enterprise Development Programme (MEDEP) is launched in the country with technical and financial support of United Nations development Programme (UNDP) since 1998. Parbat and Baglung districts are selected for the purpose of fieldwork. Objectives of the study are to identify practices of business registration, nature and types of enterprises, location of business, conducted of main business and entrepreneurs manage their business premises. The study is based on survey research approach. Data are collected through primary sources. Both qualitative and quantitative data have been used in this study. The result shows that out of total respondents 78.6 percent respondents did not register their firm in concern authority. Main reasons for not registered their business in concerned authorities is as follows: respondents have no knowledge, lengthy procedures; registration office is too far, costly, difficult to fill in the forms, and other reasons for not being registered. The result of study shows that out of total micro enterprises, 83.9 percent enterprise belongs to sole proprietorship and 10.8 percent belongs to partnership. To identify nature of business, there were given seven options. It is found that out of total respondents, near about fifty percent entrepreneurs have agro-based enterprises, 15.8 percent and 15.2 percent entrepreneurs have forest -based enterprise, and skilled-based enterprises respectively. The result shows that most of the entrepreneurs conducted their business in rural area i.e. 90.6 percent. An attempt has been made to identify conducted main business through questionnaire and it is found that out of total entrepreneurs, more than two third entrepreneurs conducted their business in their own land and building. Another survey result showed that 80.6 percent entrepreneurs arrange their business premises in without rent. It seems that most of the entrepreneurs conduct their business in rent free premises.
\end{abstract}

Keywords: Business, entrepreneurship, loation, micro enterprise, rural area

\section{Introduction}

Entrepreneurship is a process of creating new business venture. It is also the processes of identifying opportunities in the market place, arranging resources required to exploit the opportunities for long term benefits. Generally, it requires some key elements of entrepreneurship such as the entrepreneur, opportunity, resources, organization, creativity, innovation and appropriate environment. It also known as is doing something differently. Small is beauty. 
Micro enterprise may be defined as a very small or tiny business enterprise and operated by a few number of people including the owner him/herself with a little amount of capital in local area where raw materials, resources, and skills are available. The owner performs the role of manager as well as a role of the labour. S/he arranges all resources including raw materials, labour, capital, skills, and other resources to operate the business. Such types of business are found elsewhere. Each and every country encourages the role of micro enterprise with the aims of employment generation through utilization of locally available resources in doorsteps. Now, it is taken as a main instrument of poverty alleviation in Nepal. The word 'micro enterprise' is used first time in ninth five year national plan as a means of poverty alleviation and it is incorporated with the name of micro enterprises development programme (MEDEP) in 1998. The MEDEP launched by the Government of Nepal (GON) with the financial and technical support of United Nations development programme (UNDP) is working with main objective of poverty alleviation through developing micro enterprise and creating off-farm employment opportunities for rural poor and socially excluded people. The GON and UNDP started implementing MEDEP with an objective to promote off farm employment and, in particular, cater to the needs of social exclude groups and those living below the poverty line (Pun, 2010). MEDEP was started to support and to achieve the Ninth Plan's objective of poverty alleviation through the creation of micro-enterprises and creating off-farm employment opportunities for rural poor and socially excluded ( Haugen \& Vik, 2008).

International experience also reveals that micro-enterprise development has a good appeal for rural poverty alleviation in developing agrarian countries like Nepal, India, Bangladesh, Indonesia, Thailand and others have already shown successful examples. Even some developed countries have started promoting micro-enterprise for improving income and employment in the lowest income strata with the learning from micro credit approach in the east (GON/MOI, 2012).

Howeer, some government efforts towards development of entrepreneurship in Nepalese people begin in Rana regime specially in cottage and rural industrial sector.

\section{Concept of Micro Enterprise}

The "Micro-Enterprises"- a term now commonly used to refer to the very small industrial units-forms a significant sector of the economy; in most developing countries of Asia and Africa (Vepa, 1994). He mentioned that the micro enterprises sector consists of four sub sectors i.e. manufacturing, service, trade, and construction. He tried to highlight policy package for micro-enterprises, identification of opportunities, choice of entrepreneurs, entrepreneurship development programme (EDP), credit, technology, support services, role of non-government organization (NGO), and procedures and policies regarding micro enterprises.

In developing countries, the informal sector is an important source of employment. The World Bank claims that between one third and three quarters of total employment in most developing countries is in the informal sector (The World Bank, 2012). 
Micro enterprises are usually owned and operated by one individual or household and seldom engage in formal contractual agreements with bank, suppliers, customers, or other stakeholders (Roy and Wheeler, 2006).

Micro-enterprise is a tiny industry usually of $10-15$ people that is profit-oriented and may be owned by a man or a woman. A small economic activity is also known as micro enterprise. Micro-enterprise is the key to economic empowerment and social change for women (Howarth and Langdon, 2000).

The industrial Policy 2011 defines a micro enterprise (GON/MOI, 2011). as where investment is up to two hundred thousand rupees as fixed capital except the house or land; where the entrepreneur himself/herself engaged in management; where there are up to nine workers including the entrepreneur; where the annual financial transaction is less than two million rupees, and if an instrument with engine is used, the electric motor or other oil engine capacity has to be less than ten kilowatt.

In Thailand, micro enterprise refers those enterprise where involved 1-4 workers and investment of capital up to Bhatt 500,000.00 (ILO. J, 2000).

Government of India (GOI), Ministry of Small and Medium Industry, defined micro enterprise (manufacturing sector) as "does not exceed twenty five lakh (Rs 25, 00,000) investments on plant and machinery" and micro enterprise (service sector) defined as "does not exceed ten lakh (Rs 10, 00,000) investments in equipment" (Government of India ,2006).

The economic benefits of sustainable micro entrepreneurship in LDCs are compelling and its potential effects on the development process are equally promising. The process of sustainable micro entrepreneurship combines to other a potential alleviation solution to the poverty crisis of the $21^{\text {st }}$ century and into a sustainable future (www.gdrc.org.).

\section{Significance of Micro Enterprises in Nepal}

In rural areas, there were found a few opportunities of extension and development of large scale industries due to lack of adequate physical infrastructure and availability of adequate human resources and raw materials. Therefore, establishment and operation of micro enterprises are one of the best alternatives for industrial development in Nepal. These types of enterprises can be run by entrepreneurs having a little capital and few resources. Nepal is a landlocked, a least developed, and poor country. In such situation, micro enterprises are more suitable business in the path of industrial development process in the country. Such business can be run with the use of local resources, local skills, and locally available raw materials and goods can be sold within local or neighbor market. It helps to generate extra revenue, reduce unemployment problems, and proper use of leisure time after harvesting of crops and before time periods of cultivation of crops. Therefore, micro enterprise plays vital role in the context of entrepreneurship development sectors as well as industrial development sector in the country. 
Objectives of the study are to identify practices of business registration, nature and types of enterprises, location of business, conducted of main business and entrepreneurs manage their business premises.

\section{Data and Methods}

The study is based on survey research approach. Both types' sources of data i.e. primary and secondary sources are used. Both qualitative and quantitative data are used in this study. A random sampling method is adopted to select respondents. Micro entrepreneurs of Parbat and Baglung district are taken as respondents. It is assumed that total population of the study area the numbers of micro enterprises created by the MEDEP in Parbat and Baglung districts. Sample size is 360 micro enterprises which is near about $12 \%$ of total populations. Mainly, primary sources of data are widely used. Primary data are collected through structured questionnaire, personal interview, and group discussion. Secondary sources of data are collected from the office of MEDEP and DMEGA specially.

\section{Result and Discussion}

\section{Business Registration}

To find out whether micro enterprises are registered or not, the researcher asked a question to entrepreneurs. The result shows that out of total 358 respondents only 21.4 percent i.e. 78 respondents registered their firm in concern authority and 78.6 percent i.e. 280 respondents did not register their firm.

The result also shows that out of total 348 respondents, only 80 respondents registered their business enterprises, which come to nearly 23 percent. This means 77 percent (more than three fourth) of the respondents did not register their business (Shrestha, 2007).

Both study produced similar results in the case of registration of the business firm in Nepal.

To know the reasons for not being registered, questions were asked: what are the main problems regarding registration. Respondents have given six options. The result was found that out of 280 respondents 32.5 percent respondents have no knowledge, 18.8 percent respondents felt lengthy procedures, 14.8 percent respondents felt registration office is too far, 11.2 percent respondents felt costly, 1.1 percent respondents felt difficult to fill in the forms, and 21.7 percent respondents expressed other reasons for not being registered.

The result of other similar study shows that out of those 80 respondents also 57 of them never felt the need to register their businesses. Surprisingly entrepreneurs responding it as costly or difficult were far less in number totaling 4 each respectively (Shrestha, 2007).

\section{Nature and Types of Enterprises}

To overview the micro enterprise profile, the researcher had tried to collect information regarding types of the ownership of enterprise, nature of business, business location, where 
does this business conduct its main business, how did entrepreneur manage this business premises, at which markets did entrepreneur sell most of your products/services, and did entrepreneur draw salaries from the firm.

\section{Forms of the Ownership of Enterprise}

Table 1: Forms of the Ownership of Enterprise

\begin{tabular}{lcc}
\hline & Frequency & Percent \\
Proprietorship & 303 & 83.9 \\
Partnership & 39 & 10.8 \\
Private Company & 1 & 0.3 \\
Co-operative & 2 & 0.6 \\
Others & 16 & 4.4 \\
Total & 361 & 100.0 \\
\hline
\end{tabular}

Sources: Field Survey

The result of study which present in table 1 shows that out of 361 micro enterprises, 83.9 percent enterprise belongs to sole proprietorship, 10.8 percent belongs to partnership, 0.6 percent belongs to co-operative, 0.3 percent belongs to private limited company and 4.4 percent belongs to other types of ownership.

Result of a study report revealed that out of total registered cottage and small industries in Nepal under department of cottage and small industry, 87.6 percent firms registered under private or sole proprietorship, 10.8 percent registered under partnership firm and 7 percent registered under private limited company (Karki, 2012).

\section{Nature of Business}

To identify nature of business, there were given seven options. Out of 361 respondents, 49.9 percent entrepreneurs have agro-based enterprises, 15.8 percent entrepreneurs have forest -based enterprise, 15.2 percent entrepreneurs have skilled-based enterprises, 6.1 percent entrepreneurs have manufacturing-oriented, 5 percent entrepreneurs have serviceoriented and trade, 2.5 percent entrepreneurs have tourism-based enterprises, and 0.6 percent entrepreneurs have other types of enterprises.

In Parbat district, there was identified various types of micro enterprises such as agro based enterprise, forest based enterprise, services based enterprises, etc. Out of total micro enterprise, there were found agro-based enterprise of about 58.3 percent, forest-based enterprise of about 10.2 percent, tourism-based enterprise of about 5.1 percent and service based enterprise of about 4.3 percent (Karki, 2015). 


\section{Figure 1: Nature of Business}

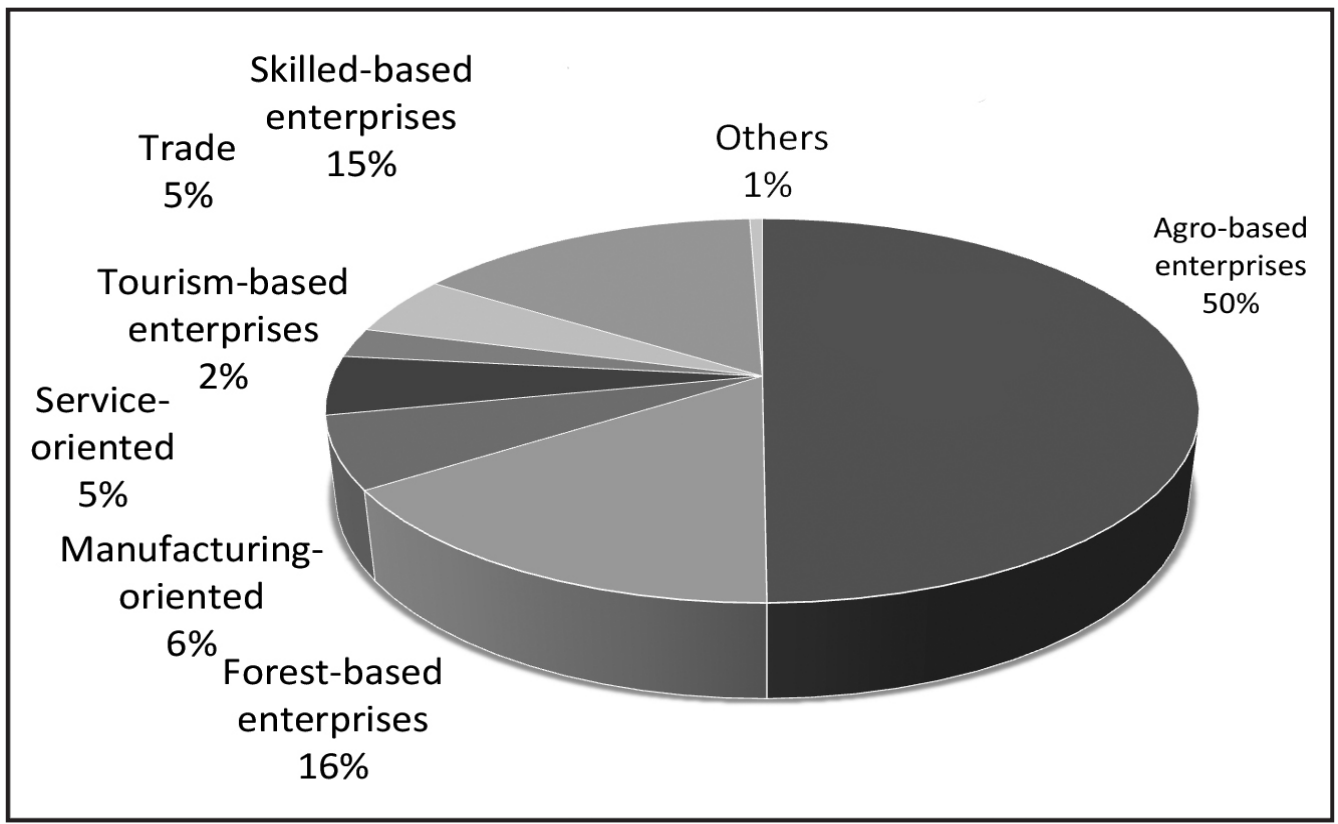

\section{Location of Business}

To identify location of business, there were given two options, they were: urban and rural area. The result shows that most of the entrepreneurs conducted their business in rural area i.e. 90.6 percent entrepreneurs conducted their business in rural area. Most of the micro enterprises are operating in rural area due to availability of raw materials, skills and other resources.

Urban area naturally attracts the entrepreneurs to set up their business establishments and/or markets their products. Out of 330 respondents, the $85.45 \%$ of business establishments are in urban areas and the 14.55 percent in rural areas (Shrestha, 2007).

\section{Conducted of Main Business}

An attempt has been made to identify conducted main business through questionnaire and it is found that out of 360 entrepreneurs, 68.1 percent entrepreneurs conducted their business in their own land and building, 18.1 percent entrepreneurs conducted their business in rented land and building, 12.8 percent entrepreneurs conducted their business in Common facility centre (CFC), 0.8 percent entrepreneurs conducted their business in no fixed location, and 0.3 percent entrepreneurs conducted their business in customer's house.

With respect to business location, the 36.07 percent of the entrepreneurs reported operating their business at their own commercial place, followed by 28.45 percent doing business from rented places. The lowest percentage in this category $(1.17 \%)$ is running through mobile services without any fixed location (Shrestha, 2007). 


\section{Entrepreneurs Manage Their Business Premises}

The survey result showed that 80.6 percent entrepreneurs arrange their business premises in without rent, 13.9 percent entrepreneurs manage their business premises in rented or leased with long term contract, and 5.6 percent entrepreneurs manage their business premises in daily or short term usage fee. It seems that most of the entrepreneurs conduct their business in rent free premises.

On the question of business premises, the 56.32 percent of respondents said that they were operating their business from the rented place, whereas the 32.76 percent said that are running from their own promises. The 8.05 percent said that they have managed their places with short-term arrangement or on daily rent. Only 2.87 percent have operated at rent-free places. Result of a study showed that entrepreneurs had to run their business from the rented or leased places. The reason is obvious. Every one may not be lucky enough to run the business from his/her places. But a sizable number of respondents were found to be running from their own premises (Shrestha, 2007).

\section{Conclusion}

Entrepreneurship assume as a means of self-employment, employment creation and economic development \& growth of the nations. The result shows that out of total respondents 78.6 percent respondents did not register their firm. The result of study shows that most of micro enterprise belongs to sole proprietorship. To identify nature of business, there were given seven options. Micro entrepreneurs conducted their business based on agro enterprises, forest enterprise, skilled, manufacturing, service and trade, tourism enterprises, and other types of enterprises. The result shows that most of the entrepreneurs conducted their business in rural area It is also revealed that during the field visit, most of the micro enterprises are operating in rural area due to availability of raw materials, skills and other resources. An attempt has been made to identify conducted main business through questionnaire and it is found that more than two third entrepreneurs conducted their business in their own land and building. The survey result showed that 80.6 percent entrepreneurs arrange their business premises in without rent. It seems that most of the entrepreneurs conduct their business in rent free premises. It is recommended that people of semi-urban and urban area also encourage involving in micro enterprise sectors and entrepreneurship development program. They can be benefited from self-employment opportunities, create employment opportunities and generate income through such activities.

Acknowledgment. I am grateful to Prof. Dr. Dev Raj Adhikari for his productive encouragement and relentless support to enhance my occupational and academic career. This research work is a part of the researcher under the aegis of Ph. D. thesis writing students' research fieldwork program, Patna University, Patna, India and is prepared with the financial support of University Grants Commission, Nepal (UGC/ Nepal). 


\section{BIBLIOGRAPHY}

Government of India (2006). The gazette of India (extraordinary) part II, section 3, subsection (ii) No. 1152 (Saturday, September 30). New Delhi: By Authority

Government of Nepal, Ministry of Industry. (2011). Industry policy 2011. Kathmandu: GON/MOI

Government of Nepal, Ministry of Industry. (2012). Micro-Enterprise Development for Poverty Alleviation (MED-PA) Programme Document (2012/13-2016/17). Kathmandu: GON/MOI

Haugen, M. S., \& Vik, J. (2008). Farmers as entrepreneurs: The case of farm-based tourism. International Journal of Entrepreneurship and Small Business, 6(3), 321-336.

His Majesty's Government/Nepal, National Planning Commission. (1998). Ninth five year plan (1997-2002). Kathmandu: HMG/N, NPC

Hwarth, R., \& Langdon, K. (2000). Organizion self-helf group. DWCP Puplication, Government of India.

International Labour Organization. (2000). Micro and small enterprise development and poverty alleviation in Thailand [Support services for policy programme development. UNDP Project THA/99/003 Micro and Small Enterprises: Giants in employment and development report and recommendations East Asia multidisciplinary advisory team Bangkok, Thailand (CISBN 92-2-012069-0) June.

Karki, B. B. (2012). Practices and trends of small and micro enterprises development in Nepal. Janapriya Journal of Interdisciplinary Studies, 1(1).

Karki, B. B. (2015). Micro Enterprise Development Programme in Nepal: A Case Study of Parbat District. Aatm Manthan, 1(1).

Khatri Chhetri, J. B., \& Karmacharya, K. (2003). Micro and small enterprises policy review in Nepal survey of micro and small enterprises' owner's/managers third component report. Kathmandu: GON, ILO, UNDP/MEDEP.

Pun, L. (2010). An introduction to micro enterprise development model and its achievements in Nepal. Micro Enterprises Development for Poverty Alleviation, 1,

Roy, M. A., \& Wheeler, D. (2006). A survey of micro-enterprises in urban West Africa: Drivers shaping the sector. Development in Practice, 16(5), 452-464.

Shrestha, R. (2007). Entrepreneurship development in Nepal. Unpulished doctoral thesis, Faculty of Management, Tribhuvan University.

The World Bank. (2012). World development report-2012; Gender equitity and development. Washington DC: The World Bank.

Vashisht, S. (2005). Study of group dynamics in self-help groups micro-enterprise in Haryana State stud of group. Unpulished doctroal thesis, Department of Home Science, University of Delhi.

Vepa, R. K. (1994). Promotion and protection of micro-enterprises in the developing countries, summary of presentation to be made at the international conference on SMEs at Addis Ababa on March, 9 (SME master plan). 